\title{
Fusidic Acid/Betamethasone Valerate Topical Cream
}

National Cancer Institute

\section{Source}

National Cancer Institute. Fusidic Acid/Betamethasone Valerate Topical Cream. NCI

Thesaurus. Code C78833.

A topical cream formulation of the bacteriostatic antibiotic fusidic acid and the synthetic, long-acting glucocorticoid betamethasone valerate with potential anti-bacterial and immunomodulating activities. Fusidic acid/betamethasone valerate topical cream inhibits Gram-positive bacterial protein synthesis and replication and inhibits the inflammatory response by preventing phospholipid release, inhibiting eosinophil activity, and decreasing pro-inflammatory cytokine production. 